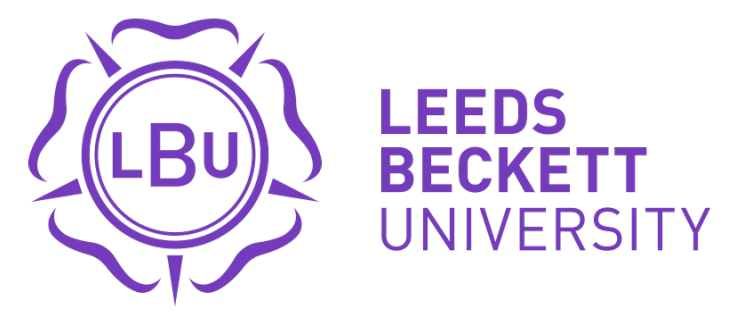

Citation:

Olanipekun, AO and Oshodi, OS and Darko, A and Omotayo, T (2019) The state of corporate social responsibility practice in the construction sector. Smart and Sustainable Built Environment, 9 (2). pp. 91-111. ISSN 2046-6099 DOI: https://doi.org/10.1108/sasbe-11-2018-0056

Link to Leeds Beckett Repository record:

https://eprints.leedsbeckett.ac.uk/id/eprint/6801/

Document Version:

Article (Accepted Version)

This is an Accepted Manuscript of an article published by Emerald in Smart and Sustainable Built Environment on 11th December 2019, available online: http://www.tandfonline.com/10.1108/sasbe11-2018-0056

The aim of the Leeds Beckett Repository is to provide open access to our research, as required by funder policies and permitted by publishers and copyright law.

The Leeds Beckett repository holds a wide range of publications, each of which has been checked for copyright and the relevant embargo period has been applied by the Research Services team.

We operate on a standard take-down policy. If you are the author or publisher of an output and you would like it removed from the repository, please contact us and we will investigate on a case-by-case basis.

Each thesis in the repository has been cleared where necessary by the author for third party copyright. If you would like a thesis to be removed from the repository or believe there is an issue with copyright, please contact us on openaccess@leedsbeckett.ac.uk and we will investigate on a case-by-case basis. 


\section{The State of Corporate Social Responsibility Practice in the Construction}

Purpose: The development of corporate social responsibility (CSR) in the construction sector is slow, thereby leaving many opportunities for further development. To enable operators in the construction sector to effectively capitalise on the opportunities to promote the development of CSR in the sector, this study employs the practice viewpoint to take the stock of CSR activities in the sector. The aim is to reveal the state of CSR practice in the construction sector. The study also draws from the development of CSR in the manufacturing, mining and banking sectors to inform the state of CSR practice in the construction sector.

Method: This study carries out a systematic literature review of 56 journal publications that were published between the year 2000 and 2016. The deductive coding of the publications was done to identify four themes of CSR research that constitute the practice view of the state of CSR in the construction sector.

Findings: The implementation of CSR is the major emphasis in the state of CSR practice in the construction sector. The implementation of CSR is wrapped in the perception of operators about CSR potentials, dimensions of CSR implemented, strategies for implementation and the effects of the implemented CSR practices on performance. The sector characteristics and organisational structure are attributes for comparing the CSR practices between the construction sector and the manufacturing, mining and banking sectors.

Originality/value: This study provides a researchers' view of the state of CSR in the construction sector. Additionally, the study draws from the development of corporate social responsibility in the manufacturing, mining and banking sectors to inform the state of CSR practice in the construction sector.

Keywords: Corporate social responsibility, construction sector, development, review 


\section{Introduction}

Corporate social responsibility (CSR) is a concept that is based on the notion that in the conduct of business, there is an implied agreement between businesses and the society. Such agreement represents the

expectation of the society from businesses to operate in a particular manner that protects the long term interests of the society instead of chasing after immediate profits (Cadbury, 2006). As a result, the concept of CSR is widely embraced across different sectors whose business activities generate substantial societal interests. Some of these sectors are the financial services, trade and retail and the extractive sectors. Equally, the construction sector is part of this group because its activities impacts negatively on the society.

According to Lu, Ye, Flanagan, and Ye (2015), the construction sector is not responsible, and poorly reputed in the area of social responsibility (Barthorpe, 2010). Excessive resources and energy are used in the execution of different construction activities such as the processing and transportation of raw materials, actual construction, operation and utilisation of building products (Zhao, Zhao, Davidson, \& Zuo, 2012). As a result, the environment and the ecosystem are affected through these activities in the forms of excessive dusts, air pollution, carbon and greenhouse gas emissions (Barthorpe, 2010; Ozorhon, 2013; Zou \& Couani, 2012). Furthermore, the nature of construction activities is labour intensive with high rate of exposure to accidents. This makes the undertaking of construction very unhealthy and unsafe for construction workers (Close \& Loosemore, 2014; Jiang \& Wong, 2016). For instance, the construction sector records a higher number of annual rate of fatal injuries to workers than in other sectors such as manufacturing, waste and recycling and agriculture in the UK in the year 2016 to 2017 (Health and Safety Executive, 2017). At the same time, many construction companies are still engaged in globally condemned practices such as Child labour (Jiang \& Wong, 2016; Lu, et al., 2015).

Therefore, CSR is widely promoted to curtail or eliminate irresponsible practices that harm the society in the construction sector. According to Othman \& Mia (2008), the construction sector is part of the societal system, and should engage in the activities that enhance the system. In the construction sector, clients are increasingly showing concern and demanding the implementation of CSR from construction companies (Close \& Loosemore, 2014; Griffith, 2011; Mayr, 2015; Myers, 2005; Roberts, et al., 2009). Such concerns are often expressed in the form of organised protests to eliminate bad practices in the construction sector (Close and Loosemore, 2014). In addition, there is a growing belief among construction sector operators such as clients, contractors, developers and consultants that the implementation of CSR practices adds value to business through positive image building and branding prestige in the construction sector (Othman \&

Mia, 2008; Roberts, et al., 2009).

Meanwhile, there are still opportunities to promote the development of CSR in the construction sector due to many lagging issues. For instance, according to Xia et al. (2018), the contributions of CSR to ensure 
sustainable development in the construction sector is limited due to the traditional approach to construction and the lack of appropriate regulations to drive responsible practices such as the recycling of construction wastes. Whitewashing of CSR practices can still be found in many construction organisations. Many are opportunistic about CSR practices (Ulutas et al., 2016). For instance, many construction organisations carry out CSR practices for sinister objectives such as to gain financial benefits only (Upstill-Goddard et al., 2016; Lichtenstein et al., 2013). In addition, despite the awareness of the benefits of CSR in the construction sector (Ulutas et al., 2016), how to effectively strategise and implement CSR practices to achieve positive outcomes is still a challenge for construction operators (Xia et al., 2018). However, to enable the operators in the sector effectively capitalise on the opportunities for the development of CSR in the construction sector, there is need to take the stock of CSR activities in the sector. This means to reveal the state of CSR practice in the construction sector. Consequently, the specific areas of CSR that needs to be improved can be revealed.

The aim of this study is to reveal the state of CSR in the construction sector from researchers' viewpoints. Therefore, the methodological approach in this study is the exploration of published literature using a systematic literature review method. Recently, Lin et al. (2018) employed this approach to explore CSR in the management field to suggest contributions for CSR in the construction sector. The difference in this study is drawing on the development of CSR in the manufacturing, mining and banking sectors, to compare

and inform CSR practice in the construction sector. Similar to the construction sector, the provision of services in these sectors create an element of social responsibility or irresponsibility. In addition, these sectors have a stronger CSR performance (Handayani, Wahyudi, \& Suharnomo, 2017; Selmier, 2017; Jenkins, 2004) that can serve a basis to inform CSR in the construction sector. This study is significant for the following reasons. The knowledge of the state of CSR practice can serve as a benchmark for future practical and theoretical suggestions for developing CSR in the construction sector. New research areas, and courses of action for the development of CSR in the construction sector can be identified. Drawing on other sectors provide an inter-sectoral comparison and lessons for developing CSR in the construction sector. In terms of structure, following this section, the next section is a review of CSR in the manufacturing, mining and banking sectors to identify areas of CSR development. Next is the method section, followed by the results and conclusion.

\section{Corporate social responsibility in other sectors}

According to Rogers (2017), CSR means different things in different sectors. Although, this study is focused on the construction sector, the review in this section is to provide a succinct overview of CSR in other sectors (Summarised in Table 1). It will also show the developments in the CSR in these sectors. CSR in the manufacturing, mining and the banking sectors are identified. As mentioned previously, the means 
through which services are created in these sectors create an element of social responsibility (or irresponsibility) in a similar manner to the construction sector. Both the manufacturing and the mining sectors have disruptive production processes, while the banking transactions often involve a set of promises exchanged between buyer and seller (or demand and supply side in construction) under conditions where it is often difficult for buyers (or clients in construction) to evaluate these promises in the absence of full information (Sallyanne Decker, 2004).

\subsection{Manufacturing sector}

Owing to the avaricious growth of manufacturing activities since the $21^{\text {st }}$ century, which has resulted to irreversible environmental impacts such as the greenhouse effect, CSR has become a primary management approach for addressing public concerns and compliance with increasing environmental regulations (Panayiotou, et al., 2009). Notably, greenhouse effect is a major environmental problem in the manufacturing sector (Moowaw, 1996). For instance, the green corporate social responsibility is promoted in the manufacturing sector to address the emission of wastes and pollution during production and to ensure the effective utilisation of resources (Guo et al., 2015). According to Handayani, et al. (2017), CSR practices such as green innovation improves environmental sustainability and social welfare of customers in the manufacturing sector. Thus, many companies have responded to environmental concerns in the manufacturing sector by making their products more energy and fuel efficient (Rogers, 2017).

There are different motivations for the adoption of CSR in the manufacturing sector. A common one is to improve business efficiency and to satisfy customers (Handayani, et al., 2017; Panayiotou, et al., 2009). Li, et al. (2017) reveal that CSR helps the manufacturing companies to build better reputations, gain the trust of customers and investors, establish steady relationships with suppliers and employees, and enjoy preferential government policies. As a consequence, manufacturing firms with higher CSR performance have higher firm value and are more sustainable and competitive ( $\mathrm{Li}$, et al., 2017). Media attention (or exposure to media) is also a motivating factor for manufacturing firms to engage in CSR. Particularly the large manufacturing companies, the media is known to expose their misdeeds, and to avoid media exposure, these companies are inclined to embrace good practices in the conduct of their businesses (Li, et al., 2017). Consequently, many manufacturing companies are more socially active with the external stakeholders such as the media to project an image of better CSR performance (Handayani et al., 2017).

Furthermore, the governance approach in the manufacturing value chain dictates the CSR compliance in the sector. As demonstrated by Lund-Thomsen and Nadvi (2010), the vertical governance structure enhances CSR compliance in the sector. In the value chain, the vertical governance promotes a centralised dictation of production processes to the manufacturing companies. Additionally, many manufacturing companies do engage in CSR reporting (Panayiotou, et al., 2009) to account for good CSR methods and 
practices (Tan-Mullins \& Mohan, 2013). Still, more opportunities for CSR improvements exist (Li, et al., 2017; Nodoushani, 2013), particularly to address the issues of labour relations and employee health and safety (Rogers, 2017).

\subsection{Mining sector}

Mining is a dangerous activity that involves the extraction of raw materials from the earth (Selmier, 2017). Mining is also capable of inducing negative effects such as entrenching existing power asymmetries in a country, exacerbating conflicts, and impoverishing populations (Tang-Lee, 2016). Therefore in the sector, key elements of CSR such as public engagement and/or stakeholder management are necessary to overcome the negative effects of mining activities such as mining conflicts between the host communities and mining companies (Tang-Lee, 2016). Where the host communities see themselves as victims, reciprocal responsibility is often carried out (Abuya, 2006).

Equally in this sector, legitimacy and identity of mining companies are important. Globally, mining companies are often located outside of the mining locations, some of which are in unfamiliar territories and remote locations with socio-political issues (Selmier, 2017). Thus, mining companies participate in community development initiatives such as provision of basic infrastructure to identify with their host communities and legitimise their business (Patnaik et al., 2017). Similar to the manufacturing sector, mining companies interact with the host communities through CSR reports. In such reports, CSR activities are framed in terms of community relations, and to identify with the community, thereby positioning their business at the centre of heart of the community members (Jenkins, 2004). Wirth, Kulczycka, Hausner, and Koński (2016) reveal that CSR in the mining sector in developing countries is focused on improving the living conditions in host communities such as provision of basic infrastructure, while in developed countries, it is focused on reducing the negative impact of mining activities. According to Wirth, et al. (2016), the difference is due to the differences in CSR policies in both categories. Hence, a domestic regulation for mining activities is essential in the mining sector (Andrews, 2016). Instead of acting out of arbitrariness, such regulation provides a guideline of engagement in CSR for mining companies to identify and implement necessary CSR practices that are beneficial to their host communities (Abuya, 2016; Andrews, 2016).

In the mining sector, the size of mining companies often determine how CSR is approached and practiced. For instance, the study of Wirth, et al. (2016) among copper mining companies around the world reveals that the large sized ones have robust CSR policies covering issues relating employee health and community engagement strategies in place. In addition, the large companies are very transparent in their CSR practices through regular CSR reporting. In contrast, the smaller companies are less transparent about their CSR 
goals, and they focus on engaging in ad-hoc issues, rather than developing long-term strategic relations (Wirth, et al., 2016).

\subsection{Banking sector}

According to Shen, Wu, Chen, and Fang (2016), the importance of CSR in the banking sector is commonly exemplified in three common forms. Firstly, from the regulator and public view, engaging in CSR is a means for the banks to compensate for the use of societal resources. The public, through bank customers entrust their savings and other financial investments to the banks, which are consequently used by the banks for other productive ventures (Sallyanne Decker, 2004). Secondly, from the managerial point of view, banks sell different products that are at best intangible to their customers, many of whom are not financially sound to understand the nature of these products. Due the intangibility of many bank products, these customers cannot sample them before subscribing (Sallyanne Decker, 2004). Thus, the banks need to demonstrate a lot of trustworthiness and reputation through CSR actions to attract customers (Shen, et al., 2016). Thirdly, bank lending is critical to the growth of businesses such as gun production, blood diamond and casinos operation that are societally damaging. To reverse any trend in this direction requires the commitment and

pledge of banks to desist from financing such businesses. For instance, banks can familiarise with the financial affairs of their customers to prevent them from engaging in damaging investments (Guo, 2012).

It could be seen that the three forms reflect a form of external influence, by both the regulators and the public through bank customers.

However, there is growing emphasis on the CSR that reflects the internal aspects in banks. From the employee perspective, the argument is that the actions/values of a bank that enhances the connection to employees are reinforced in ethics, and deepened attention to CSR (Valentine \& Godkin, 2017). According to Mensah, Agyapong, and Nuertey (2017), actions that increase banks' perception of CSR will enhance employees' fit and commitment to their employer, thereby reducing any intention to quit working for the employer (Valentine \& Godkin, 2017). Additionally, bank employees appreciate the CSR initiatives implemented in their organisations because it helps to develop a highly regarded corporate brand in the society (Bravo, Buil, de Chernatony, \& Martínez, 2017). This suggests that employees are very important to the development of CSR in the banking sector. Equally, bank managers have crucial roles to play such as: developing and implementing appropriate ethics policies and providing leadership and bonding to employees (Bravo, et al., 2017; Valentine \& Godkin, 2017). According to Sallyanne Decker (2004), it is well recognised, especially among managers in the banking sector that the concept of CSR influences their operating environment with vital consequences for their performance and survival. For example, CSR is highly regulated in the banking sector (Shen, et al., 2016) which affects how banks operate (Sallyanne 
Decker, 2004). As such, banks are conditioned to develop strategies to indicate that they consider wider societal concerns that arise from their banking activities.

Often, banks would cooperate and partner among themselves, or with external organisations to deliver one or more social responsibilities (e.g. (Ali \& Rahman, 2015) as a long-term survival strategy (Shen, et al., 2016). In addition, and similar to the manufacturing and mining sectors, banks would regularly engage in

CSR disclosure to dialogue with those that are affected by their business in the immediate societies they are located (Castelo Branco \& Lima Rodrigues, 2006). The implementation of CSR in banks has been very beneficial. Shen, et al. (2016)'s analysis of global banks in 18 countries reveals that the financial performance in banks that conduct CSR practices are much greater than those that do not. In fact, the analysis of data from 194 banks in 22 countries reveals that the more CSR practices in a bank, the better the financial performance (Wu, Shen, \& Chen, 2017). However, differences in national cultures could account for the effects of CSR on performance in the banking sector. For instance, the impact of CSR in the banks in the East Asian culture of Confucianism focuses on the employee and community component of CSR practices (Bouvain, Baumann, \& Lundmark, 2013). In contrast, the impact is on green issues and caring for the environment in the Western culture. In this culture, banks that fulfil sustainability requirements experience high financial performance (Forcadell \& Aracil, 2017). However, in developing countries, banks perform very lowly in the environmental aspects of CSR (Hu \& Scholtens, 2014). In sum, the benefits of CSR to banks are not universal, mainly due to differences in national cultures.

Table 1: Summary of the areas of development of CSR in different sectors

\begin{tabular}{lccc}
\hline CSR aspects/Sectors & Manufacturing & Mining & Banking \\
\hline Community engagement & & $\sqrt{ }$ & \\
Company policy & $\sqrt{ }$ & $\sqrt{ }$ \\
Company size & $\sqrt{ }$ & \\
CSR reporting & & $\sqrt{ }$ & $\sqrt{ }$ \\
Dichotomy between developed and developing economies & & $\sqrt{ }$ \\
Employee concerns & & $\sqrt{ }$ \\
Environment & $\sqrt{ }$ & $\sqrt{ }$ \\
Governance & $\sqrt{ }$ & \\
Infrastructure provision & & $\sqrt{ }$ & \\
Legitimacy and identity & & $\sqrt{ }$ & $\sqrt{ }$ \\
Long terms vs short term (Strategic CSR) & & & $\sqrt{ }$ \\
Managerial & & & $\sqrt{ }$ \\
National culture & & & $\sqrt{ }$ \\
Partnerships & & $\sqrt{ }$ & $\sqrt{ }$ \\
Performance & & &
\end{tabular}




\section{Method}

Generally, there is a lack of widely agreed definition of CSR in theory. According to Wan-Jan (2006), this has contributed a lot of misunderstandings and cynicism towards the concept (Wan-Jan, 2006; Hamidu, Haron and Amran, 2015). Despite this, practitioners can be seen practicing CSR, and as a result, the real practice of CSR can reliably inform the concept of CSR (Wan-Jan, 2006). In line with this position, WanJan (2006) described CSR as both a business strategy and as an ethical necessity. Basically, as a business strategy, CSR can be implemented to enhance business profitability, while as an ethical necessity, profits made can be invested to care for shareholders and societal interests. Equally, studies have explored the practice of CSR through the contents of CSR reports to provide an understanding of CSR (e.g. Ayuso et al., 2016; Vigneau, Humphreys and Moon, 2015). Therefore, to achieve the aim of this study (to reveal the state of CSR practice in the sector), we will not attempt making conceptual definitions, but to explore the researchers' viewpoint of CSR in the construction sector.

There is a sizable amount of research on CSR in the construction sector. The research provides a reflection of researchers' viewpoints on the subject. Ekung, Ujene and Ubong (2014) stated that research on CSR in the construction sector had been increasing since the year 2000. Exploring published literature assures more breadth since the aggregate of the research may encompass multiple contextual characteristics such as location, professional differences and focus. In addition, such research are a source of secondary data which had passed through a rigorous primary data collection and analysis before publication. Meanwhile, a systematic approach to exploring published literature to achieve the aim of this study was preferred to summarise the body of knowledge, and consequently scope out the themes of research on the subject in line with the aim of the study (Mok, Shen and Yang, 2015).

Therefore, we employed the systematic literature review method. To ensure a rigorous review, we followed the approach of Okoli and Schabram (2010) as follows. Firstly, we carried out electronic search for relevant publications on "corporate social responsibility in construction" in the Google Scholar database. It is a very effective database for systematic selection of literature, and publications in other databases such as Springer and the ASCE database can be found in it (Morioka \& de Carvalho, 2016; Sartor, Orzes, Di Mauro, Ebrahimpour, \& Nassimbeni, 2016). Additionally, it is particularly useful because many leading construction sector journals can be sourced from it (Xiong, Skitmore, \& Xia, 2015).

Furthermore, we focused on journal publications only, while conference publications, textbooks and policy papers were left out. The reason is that journal publications are more scientifically valid than the other types of publications due to the rigorous review process (Olanipekun, Chan, Xia \& Ameyaw, 2017). Meanwhile, 
despite that research on CSR in construction has been increasing since the year 2000 (Ekung et al., 2014), it is significantly later than the field of management where research on CSR started in the 1950s (Hamidu et al., 2015). Therefore, to ensure more coverage and to obtain more publications as possible, we placed no restriction on the scope of journals that we focused on.

In the process of searching through the databases, we used a collection of keywords with the aim to whittle down too many publications (Piper, 2013). The main keyword is "corporate social responsibility." However, we incorporated other keywords that are similar in meaning and used interchangeably with the main keyword in the construction sector context. These are corporate social performance, corporate environmental performance and sustainable responsibility. Furthermore, to reflect the construction sector, we used keywords that provide the context and the environment where CSR is practiced in the sector. These are during the management of construction process, the construction organisations and the industry at large. Therefore, in the Google Scholar database, the keywords were combined with appropriate Boolean operators as follows: ((“corporate social responsibility" OR "corporate social performance” OR "corporate environmental responsibility" OR "sustainable responsibility") AND ("construction management" OR “construction project management” OR "construction industry" OR "construction organisations" OR “construction organizations" OR “construction firms")).

By means of this search strategy, 300 publications were returned. After excluding duplicated publications in the database, we downloaded 121 that were journal publications in Endnote. Subsequently, we examined the titles and abstracts of the publications to allow us make initial judgement about suitability for inclusion of publication. We observed that all but 10 of the publications contained one of the keywords in the least. In the final step, we read the full texts of the remaining 111 publications to check whether they provide insights into CSR practices in the construction sector, especially in construction organisations, projects and the sector at large. We found that, despite that one or more of the keywords are contained in the publications, 55 of them (about 50\%) provided no insights into the practice of CSR in the sector. Instead, these publications contain wishful contents about the future of CSR in the construction sector, and were therefore removed from further analysis.

Next, we embarked on the coding of the 56 publications that were retained through a deductive approach whereby categories are defined a priori by the research team (Sartor et al., 2016). We defined only one category, which is the "aim of study" for the coding of the selected publications. Actually, other codes such as unit of analysis, sample dimension and research context could be useful. However, these and others were considered by the authors earlier, and used for selecting appropriate publications. We agreed that the "aim of study" convey the meaning unit that provides the strongest insights to the themes in the publications. For instance, the aim in Xiong, et al. (2016) is to evaluate the corporate social performance - corporate financial 
performance relationship. In the study, the insight being conveyed is "the effect of CSR practice", which we regarded as the meaning unit. We used this approach to identify three other themes: (1) the perception of CSR, (2) the CSR practices, and (3) the strategies for implementing CSR practices. The Table 2 reveals the results of coding process with the number of publications under different themes. The number of publications under each theme are 10,25, 19 and 14 respectively.

To ensure the reliability of the coding process, we formed two independent groups to perform the coding (Ham-Baloyi and Jordan, 2016). With the themes identified, the coding of the publications under different themes was mostly consistent among the authors. However, we experienced very minimal cross-coding. To resolve them, we discussed the different judgements behind the cross-coding and were resolved through a discursive alignment of interpretations (Sartor et al., 2016).

Table 2: Summary of the themes of CSR research in the construction sector

\begin{tabular}{|c|c|c|c|c|}
\hline Authors & Perception & CSR practices & Strategies & Effect \\
\hline Zhao et al. (2016) & $\sqrt{ }$ & & & \\
\hline Arruda et al. (2013) & & & & $\sqrt{ }$ \\
\hline Barnes and Croker (2013) & & & & $\sqrt{ }$ \\
\hline Barthorpe (2010) & & $\sqrt{ }$ & & \\
\hline Bevan and Yung (2015) & & $\sqrt{ }$ & & \\
\hline Bowen et al. (2014) & & $\sqrt{ }$ & & \\
\hline Boyle and McGuirk (2012) & & $\sqrt{ }$ & & \\
\hline Cambra-Fierro et al. (2013) & & & & $\sqrt{ }$ \\
\hline Close and Loosemore (2014) & $\sqrt{ }$ & & & \\
\hline Eadie and Rafferty (2014) & $\sqrt{ }$ & & & \\
\hline Ekung, et al. (2014) & $\sqrt{ }$ & & & \\
\hline Glass and Dainty (2011) & $\sqrt{ }$ & & & \\
\hline Gliedt and Hoicka (2015) & & $\sqrt{ }$ & & \\
\hline Griffith (2011) & & & $\sqrt{ }$ & \\
\hline Guo (2012) & & & $\sqrt{ }$ & \\
\hline Haigh and Sutton (2012) & & & $\sqrt{ }$ & \\
\hline Huang and Lien (2012) & & & & $\sqrt{ }$ \\
\hline Jiang and Wong (2016) & & $\sqrt{ }$ & & \\
\hline Lassch and Yang (2011) & & $\sqrt{ }$ & & \\
\hline Liao, Xue, Liu, and Fang (2015) & & & & $\sqrt{ }$ \\
\hline Lichtenstein et al. (2013) & & $\sqrt{ }$ & & \\
\hline Liu, Fellows, and Tuuli (2011) & & & & $\sqrt{ }$ \\
\hline Liyanage, et al. (2016) & & $\sqrt{ }$ & & \\
\hline Loosemore (2015) & $\sqrt{ }$ & & & \\
\hline Loosemore (2016) & $\sqrt{ }$ & & & \\
\hline Lu, et al. (2015) & & & & $\sqrt{ }$ \\
\hline
\end{tabular}


Mayr (2015)

ivivituil el al. ( $\angle$ U11)

Myers (2005)

Newell and Lin Lee (2012)

Othman (2009)

Othman and Abdellatif (2011)

Othman and Mia (2008)

Petrovic-Lazarevic (2008)

Petrovic-Lazarevic (2010)

Pillania, Wuttke, and Vilks (2014)

Pivo (2008)

Pivo and Group (2008)

Rapson et al. (2007)

Roberts and Kimmet (2009)

Roberts and Kriese (2009)

Roberts, et al. (2007)

Roberts, et al. (2009)

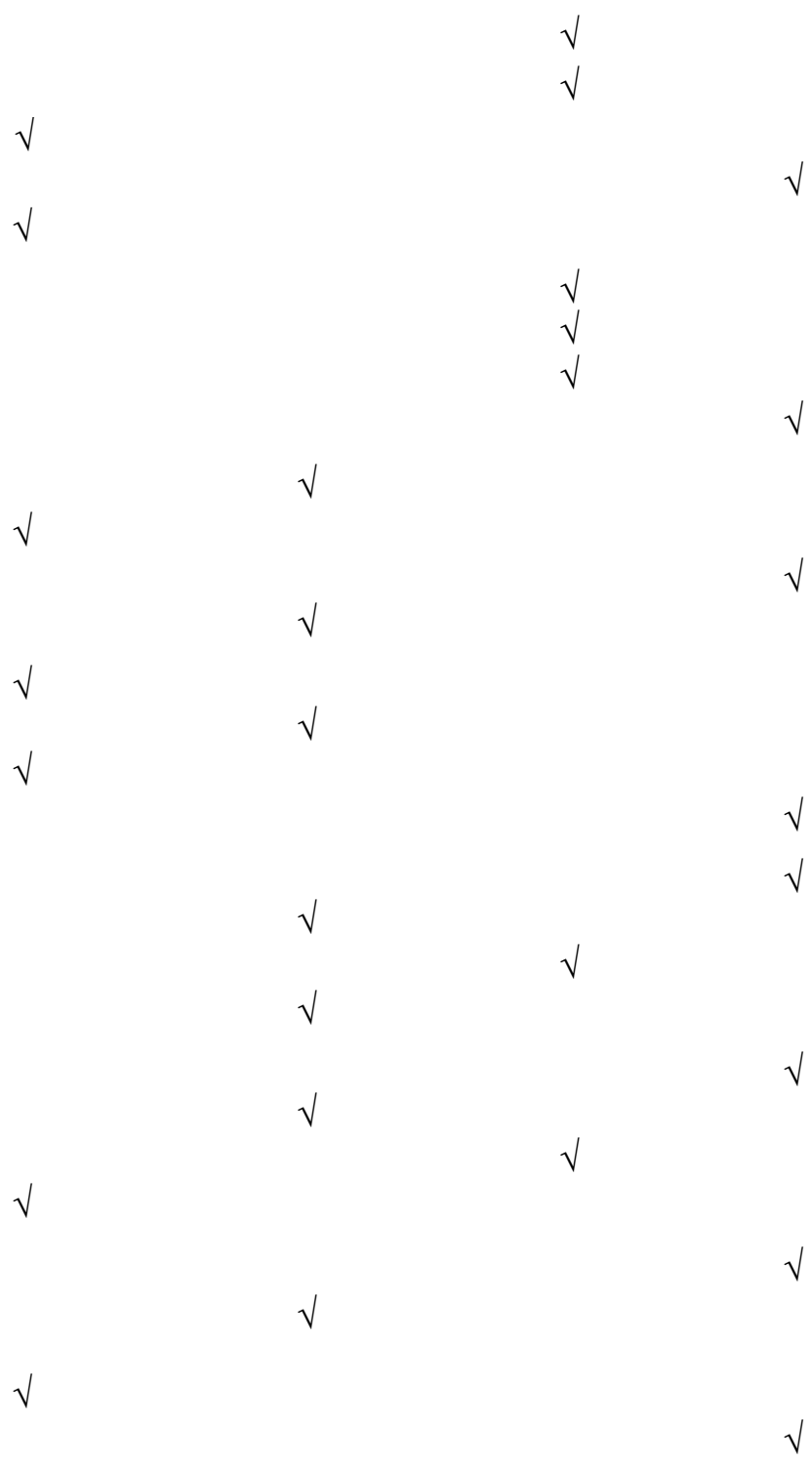

Sardinha, Reijnders, and Antunes (2011)

Shen, Tam, Tam, and Ji (2010)

Tan-Mullins and Mohan (2013)

Tsai, Yang, Chang, and Lee (2014)

Upstill-Goddard et al. (2016)

Wang, Toppinen, and Juslin (2014)

Wilson et al. (2011)

Wu et al. (2015)

Xiong, et al. (2016)

Yam (2013);

Yam Lee Hong, Ismail, and Soo Yin (2008)

$\sqrt{ }$

\section{Results}

\subsection{Distribution of publications in journals}

The 56 publications are contained in 30 different journals. This is a large spread that indicates a growing research area. The journals are categorised into construction related, sustainability related and business related journals. Expectedly, the highest number of publications were published in construction related journals (64.3\%), followed by sustainability (21.4\%) and business (14.3\%) related journals. 


\subsection{Distribution of publications in years}

As shown in the Figure 1, the publications spanned a period of 12 years (2005-2016). Although the starting period of the search scheme was the year 2000, the first journal publication was produced in the year 2005 . This is a much later time when compared to the 1950s when research on CSR in the field of management started. With the exception of 2006, no year has publication less than 2. In 2011, the number of publications reached the highest ( 9 number). Afterwards, the number of publications was consistent at an average of 6.4 publications between the years 2012-2016.

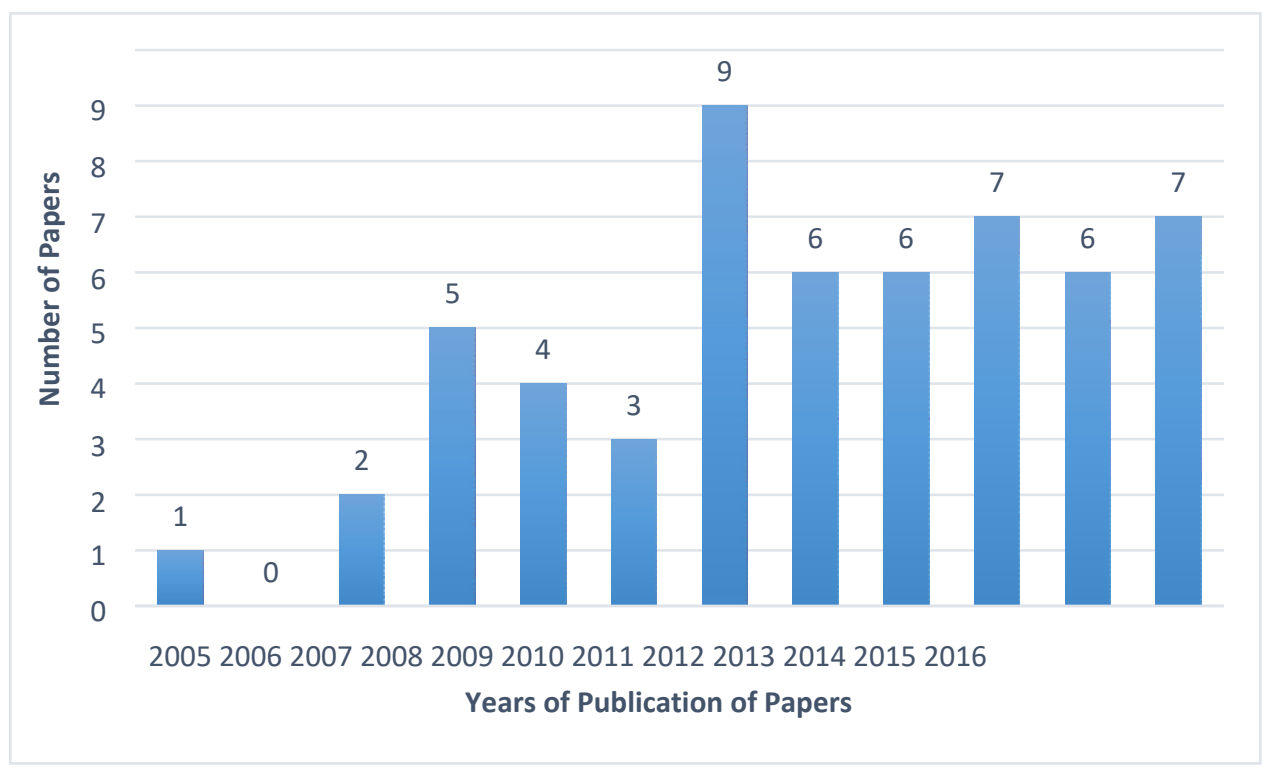

Figure 1. Distribution of papers in years

\subsection{The themes of CSR research in the construction sector}

As mentioned previously, the four themes that reveal the state of CSR practice in the construction sector are illustrated in Table 2. They are: perception of CSR, CSR practices, strategies for implementing CSR and effect of CSR practices, and are described in the following section.

\subsubsection{The perception of CSR}

This theme reveals how CSR is perceived among the operators in the construction sector. There are two diverse perceptions of CSR in the sector. The first one is that CSR is acceptable and should be implemented in the construction sector. This perception was pervasive in the early 2000s when CSR began gaining prominence in the construction sector. Being a new concept during the period, many operators in the sector such as property developers were open to the idea of CSR in construction organisations. For instance, property developers in Malaysia opine that CSR should be implemented as part of contributions to sustainable development (Hong, Ismail and Yin, 2008). Particularly, the large construction companies want to be judged on the basis of their contributions to the society and the environment (Myers, 2005). 
However, in construction organisations, this perception was only held prior to actual implementation of CSR practices. The perception is different when one or more CSR practices are implemented. The construction professionals in the organisations think that the undertaking of CSR is not a primary responsibility that concerns them. They believe that participating in the implementation of CSR practices is very burdensome, costly and time-consuming exercise (Close \& Loosemore, 2014). The negative perception of CSR is attributed to the problems encountered by construction operators owing to the characteristics of the construction sector which is inimical to the effective CSR implementation. The sector is fragmented (Ekung, et al., 2014; Loosemore, 2015; Yam Lee Hong, et al., 2008) in terms of its diverse associated processes and the related professions, which in turn affects any transition towards socially responsible practices (Loosemore, 2016; Myers, 2005). Equally, many trade organisations such as the contractors and the supervision firms exist in the sector (Wu, et al., 2015; Zhao, et al., 2016). These organisations have different organisational processes and aspirations, which contribute to the differences in perceptions about CSR in the sector. These characteristics are existential and may not easily change (or be changed) to accommodate CSR development.

\subsubsection{The CSR practices}

As pointed above, the perception of construction operators after the actual implementation of CSR is negative. Nevertheless, evidences reveal the CSR practices in the construction sector which can be categorised into the environmental, social and economic dimensions. The environmental dimension is aimed at reducing the environmental footprint of construction activities. Examples of the CSR practices in this dimension are energy upgrading in buildings (Gliedt and Hoicka (2015), use of renewable materials for building (Wang, Toppinen, and Juslin, 2014),employing low carbon emitting construction methods and

CO2 emission reduction strategies during construction (Boyle \& McGuirk, 2012; Tsai, Yang, Chang, \& Lee, 2014). The social dimension are the CSR practices that are very fundamental (Zhu, Zhao, \& Sarkis, 2011), often intangible (Lichtenstein, Badu, Owusu-Manu, John Edwards, and Holt (2013) and in the forms of values or social contribution to stakeholders, communities and other benefactors within and outside of the sector. Examples of the social dimension of CSR practices are the provision of financial donations and awards, sponsorships, training and disaster relief expertise, and employee engagements and supports. It may also be the establishment of good relationships and rapport between contractors and the communities where their construction sites are located (Lassch and Yang, 2011).

The economic dimension is often implemented in combination with the two other dimensions, such as investing in energy efficient features (environmental dimension) to save energy cost for the building users (economic dimension), while also reducing the environmental footprint of the building (environmental dimension) (Gliedt \& Hoicka, 2015). Therefore, the implementation of the economic dimension of CSR 
practices is annexed with the social and economic dimensions in the construction sector. Consequently, the implementation of CSR in the construction sector involves multiple dimensions. For instance, among responsible property developers in US, CSR practices include location, building and people dimensions (Roberts \& Kriese, 2009), while among apartment developers in China, they include environmental and social dimensions (Zhu, et al., 2011). Among the construction companies in Ghana, their CSR practices include the social, infrastructural and environmental dimensions (Lichtenstein, et al., 2013), while in both UK and Turkey, they include the ethical and social dimensions (Liyanage, Ulutaş Duman, Giritli, \& McDermott, 2016). Given the potential for the implementation of multiple dimensions of CSR at the same time, achieving a balanced implementation is necessary to ensure a comprehensive implementation, or prevent the preference of one dimension over another (Lichtenstein et al., 2013, Liayanage et al., 2016). However, to ensure a balanced implementation of CSR dimensions in construction organisations, factors such as the changing characteristics of countries, company scales, and the activity types and areas need to be taken into consideration (Bevan and Yung, 2015; Zhu et al., 2011).

\subsubsection{The strategies for implementing CSR}

As mentioned previously, the perception of CSR among construction operators, especially after the actual implementation of one or more CSR practices is negative. Equally, at the strategic level, barriers such as the adversarial working relationships of the different professional disciplines (Othman and Abdellatif, 2011), cultural and linguistic differences (Tan-Mullins and Mohan, 2013) and heavily bureaucratic governance structures (Petrovic-Lazarevic, 2008) hinder the effective implementation of CSR practices. Thus, strategically implementing CSR practices is very important to ensure success. There are a few observed strategies that can be employed for the successful implementation of CSR practices. One of the strategies is partnership among different operators in the construction sector for the provision of one or more social good(s) (Othman \& Abdellatif, 2011). It could be in the form of exchanging of ideas that reduces the environmental footprint of projects. Therefore, not only will that be a social good, it is also an environmental good through a reduced environmental impact of projects.

Often, partnership as a strategy extends beyond the construction sector whereby construction operators' partner with external organisations such as donor or relief based organisations. This is common in the situations of disasters or emergencies. According to Haigh and Sutton (2012) this form of partnership operates by initially focusing on providing philanthropic support to victims, and thereafter, gravitates to supporting the longer term business objectives of the partners. Therefore, partnership is both a strategy for

implementing CSR practices and propagating business interests. However, for partnership to work as a strategy for implementing CSR practices, it requires trust, transparency and open communication among the partners (Haigh \& Sutton, 2012). Furthermore, it is often the case in construction organisations to 
incorporate CSR practices into the business vision and mission of construction companies. Commonly, it involves the use of integrated management systems (IMS) to actualise this strategy, and the advantage is that CSR practices can be cascaded throughout the organisation and reflected in all project activities (Griffith, 2011).

Frameworks are also employed, such as that of Othman and Mia (2008) for the integration of CSR practices into the corporate mission and vision in the South African Quantity Surveying firms. Frameworks have proven to be more useful in the smaller firms. According to Mayr (2015), the use of frameworks provides a procedural guidance to entrepreneurs and owner-managers in the small firms to implement CSR practices in both short and medium terms. The strategies for implementing CSR practices cannot be effected without the sanctioning of the top management in construction organisations. The management is responsible for devising the strategies. It commits resources and trade priorities to effect the strategies (Cambra-Fierro, Wilson, Polo-Redondo, Fuster-Mur, \& Lopez-Perez, 2013) and also drives the strategies and determines

how to actualise them (Morton, Goodwin, Kellond, Close, \& Collins, 2011; Tan-Mullins \& Mohan, 2013). In addition, employees look up to the managerial guidance to key into the strategies (Haigh \& Sutton, 2012; Mayr, 2015). Meanwhile, the managerial input represents a top-down approach to CSR implementation (Mayr, 2015). In contrast, the bottom-up approach involves operational level operators such as employees in the construction organisations or sites. For instance, through the transformative social work approach, construction workers have been educating and organising themselves into collective groups to mobilise the grassroot power to enforce the implementation of social responsibilities that pertain to their own welfare within construction companies (Guo, 2012). However, the bottom-up approach requires an external support particularly from the non-governmental organisations to be more effective in the construction sector(Guo, 2012; Tan-Mullins \& Mohan, 2013).

\subsubsection{The effect of CSR practices}

With the implementation of CSR practices, the beneficial outcomes can be observed in the construction sector. According to Pivo and Group (2008), the implementation of CSR practices has beneficial outcomes.

The outcomes include improved image and business reputation (Huang \& Lien, 2012). Operationally, clients view construction organisations as responsible in their business conduct, and therefore they increase their patronage, which leads to high performance for the companies, especially in terms of profits (Huang \& Lien, 2012; Roberts, Jones, Hillier, Comfort, \& Clarke-Hill, 2009). According to Cambra-Fierro, et al. (2013), the good thing is that construction clients are particularly responsive to CSR commitments in construction organisations, by making more patronage that increases the financial and non-financial performances in the organisations. 
However, CSR commitments must neither be reactionary nor opportunistic. Reactionary in the sense of taking responsible actions after a problem has occurred, and opportunism in the sense of laying claim to responsible practices that are not genuine or untrue. Construction clients have been shown to desist from patronising construction companies whose CSR practices are either reactionary or opportunistic (CambraFierro et al., 2013). Notably, as the implementation of CSR practices lead to beneficial outcomes, so also can these outcomes influence CSR practices in construction organisations. It is regarded as a nexus relationship between CSR practices and the performance of construction organisations. As demonstrated by Xiong, et al. (2016), the CSR practices tailored towards clients and suppliers increased the financial performance of construction companies in China, while also improvements in the financial performance of the companies increased their environmental responsibility. The study also found a similar relationship between profitability and overall CSR practices in the companies. In this regard, the challenge in construction organisations is how to effectively evaluate CSR performance.

With the exception of Wu et al. (2015)'s indicators, the indicators for evaluating CSR performance are lacking in the construction sector are lacking (Zhao, et al., 2012). Wu et al. (2015)'s indicators are less useful because there are no weightings to different CSR interests and perspectives. Furthermore, the CSR indicators in the globally recognised disclosure standards such as the ISO 26000 do not adequately reflect the CSR issues in the construction sector (Jiang \& Wong, 2016; Lu, et al., 2015; Petrovic-Lazarevic, 2010; Upstill-Goddard, Glass, Dainty, \& Nicholson, 2016). Thus, they are less useful for evaluating the CSR performance of construction companies. Therefore, the challenge of evaluating CSR performance in the construction sector remains due to lack of indicators for evaluation. It remains a research issue in the construction sector (Zhao, et al., 2012).

\section{Discussion of findings: State of CSR Practice in the Construction Sector}

It could be seen that the four themes of CSR research about the state of CSR in the construction sector was obtained. The four themes are the: perception of CSR, CSR practices, strategies for implementing CSR and effect of CSR practices. The differences between the state of the art of CSR in the construction sector and the manufacturing, mining and banking sectors are also discussed. The summary is presented in Table 3 .

The first theme about the perception of CSR revealed that construction operators view and regard the implementation of CSR in a negative manner. Often, this is due to the characteristic nature of the construction sector such as the extremely diverse professions and processes which hamper transitions towards responsible practices in the sector (See Loosemore, 2016). Many professional disciplines such as Architects, Engineers, Quantity Surveyors and Builders who are engaged in different construction organisations are responsible for construction process. These disciplines tend to exhibit different organisational cultures and promote different professional interests that hampers cooperation. Construction 
processes such as designing, constructing and commissioning are many thereby making it difficult to create a harmonised front. To eliminate negative perception and promote CSR in the construction sector may thus require the transformation of the construction sector disciplines, processes and operations to be more open and susceptible to responsible construction practices. Already, the sector is increasingly embracing sustainable building practices and responsible sourcing of construction materials to eliminate the environmental footprint of building construction and operation (Zhang et al., 2019; Glass, 2011).

Construction contracting can also be reviewed to include social responsibility performance a one of the basis for contractor and vendors selection in the construction sector (Xia et al., 2018).

Meanwhile, despite the negative perception of CSR among construction operators, the second theme reveals that there are three dimensions of CSR practices implemented in the construction sector including the environmental, social and economic dimensions. The dimensions of CSR are implemented in strategic manner in construction companies. The third theme reveals that strategies such as partnership among multiple organisations to deliver social goods is common. The use of strategies ensure that the right CSR is implemented (Othman and Abdellatif, 2011; Mayr, 2015). In addition, it ensures the implementation of a CSR practice for a longer term (Kraft \& Hage, 1990). Meanwhile, Xia et al. (2018) stated that CSR practices in the construction sector are implemented for a short time. Henceforth, the use of strategy is suggested to ensure a longer term implementation of CSR in construction companies. Finally, the fourth

theme reveals that a proactive implementation of CSR practices is beneficial to construction companies. However, evaluating the performance of CSR in construction companies remains problematic due to lack of indicators for the evaluation.

The characteristic of the construction sector in terms of extreme diversity in the professions and processes seems to influence the negative view of CSR among construction operators. This is not so in the mining and banking sectors. For instance, mining activities are characteristically capable of causing conflicts, thus the pervasive social responsible actions in the mining sector are public engagements and stakeholder managements to stem the effects of conflicts among parties, especially in the host communities (Tang-Lee, 2016). Similarly, banking service is characteristically customer-centred, and thus, CSR in the banking sector is focused on developing banking employees to provide quality service to customers (Valentine \& Godin, 2017, Shen et al., 2016). Therefore, the employees play important role in the development of CSR in the sector (see (Mensah, et al., 2017; Valentine \& Godkin, 2017)). It could be seen that the sector characteristics determine the nature of social responsibilities implemented in these sectors. Consequently, the social responsibilities implemented promote the businesses of mining and banking. This is also true in the mining and construction sectors. Implementing CSR practices to improve performance in the manufacturing and banking companies (Handayani, et al., 2017; Wu, et al., 2017) is common practice in 
construction companies as well (Huang and Lien, 2012). Lesson learnt is that sector characteristics determine the CSR practices to be implemented in order to enhance business performance across the sectors.

Similarities do exist in the CSR practices in the construction sector and the other sectors. The role of the top managers in construction companies is very crucial to devising and effecting CSR strategies (Cambra-

Fierro et al., 2013) as much as in the banks (Sallyanne Decker, 2004), while CSR practices are implemented in both the construction and mining sectors by incorporating them into company mission and vision (Griffith, 2011; Wirth, et al., 2016). The structure of the organisation is therefore of importance to the implementation of CSR practices. It suggests that those in the top hierarchy are very crucial to the implementation of CSR practices. In addition, CSR practices are better implemented if embedded as organisational plans.

Table 3: Differences and similarities between the state of the art of CSR in the construction sector and the manufacturing, mining and banking sectors

\begin{tabular}{|c|c|c|}
\hline Attributes & $\begin{array}{l}\text { Comparison across construction, } \\
\text { manufacturing, mining and banking } \\
\text { sectors }\end{array}$ & Lessons learnt \\
\hline Sector characteristics & $\begin{array}{l}\text { - Construction sector: Extreme } \\
\text { diversity in the professions and } \\
\text { processes seems to influence the } \\
\text { negative view of CSR among } \\
\text { construction operators } \\
\text { - Mining sector: Conflict-proneness of } \\
\text { mining activities stimulates peace- } \\
\text { building efforts through public } \\
\text { engagement and stakeholder } \\
\text { management among interested parties } \\
- \text { Banking sector: Customer-focus in } \\
\text { the banks promotes employee training } \\
\text { and development to provide excellent } \\
\text { customer care services }\end{array}$ & $\begin{array}{l}\text { Lesson learnt is that sector } \\
\text { characteristics determine the } \\
\text { CSR practices to be implemented } \\
\text { in order to enhance business } \\
\text { performance }\end{array}$ \\
\hline
\end{tabular}




\begin{tabular}{|l|l|l|}
\hline $\begin{array}{l}\text { Organisational structure } \\
\text { the implementation of CSR practices } \\
\text { across sectors }\end{array}$ & $\begin{array}{l}\text { Tesson learnt is that an } \\
\text { organisational structure in place } \\
\text { with clear definition of position } \\
\text { and authority is necessary to } \\
\text { organisational plans across sectors } \\
\text { support CSR implementation in } \\
\text { organisations. } \\
\text { In addition, CSR practices are } \\
\text { better implemented when } \\
\text { embedded as part of } \\
\text { organisational plans (mission } \\
\text { and vision) }\end{array}$ \\
\hline
\end{tabular}

\section{Conclusion}

The development of CSR in the construction sector is slow, thereby leaving many opportunities for further development. However, to enable the operators in the sector effectively capitalise on the opportunities for the development of CSR in the construction sector, this study employs the researchers' viewpoints to take the stock of CSR activities in the sector. This reveals the state of CSR practice in the construction sector. Furthermore, the study draws from the development of corporate social responsibility in the manufacturing, mining and banking sectors to inform the state of CSR practice in the construction sector. Therefore, the conclusion of the study regarding the state of CSR practice in the construction sector are as follows.

1. The implementation of CSR is the major emphasis in the state of CSR practice in the construction sector. This signifies the attempt to put CSR into action in the organisations and projects in the construction sector. The implementation of CSR is wrapped in the perception of operators about CSR potentials, dimensions of CSR implemented, strategies for implementation and the effects of the implemented CSR practices on performance.

2. The sector characteristics and organisational structure are attributes for comparing the CSR practices between the construction sector and the manufacturing, mining and banking sectors. The sector characteristics encompass the manner in which a sector operates. The organisation structure is the arrangement of people and operatives according to the associated responsibilities and authority.

3. CSR practices in the mining and banking sectors provide important lessons for CSR practices in the construction sector. One lesson is that sector characteristics determine the CSR practices to be 
implemented in order to enhance business performance. The second lesson is that an organisational structure in place with clear definition of position and authority is necessary to support CSR implementation in organisations.

Based on the conclusion, the study provides the following recommendation

- According to the state of CSR, the CSR's emphasis on implementation suggests an increasing attempt at the actual implementation of CSR practices in the organisations and projects in the construction sector. To sustain this tempo, there is need for strong optimism about the usefulness of CSR practices, and the success of implementation. The managers and employees in different construction organisations and projects need to be committed to CSR practices to demonstrate optimism. Furthermore, to ensure that the three dimensions of CSR practices are implemented at the same time without leaving anyone out, construction organisations should be strategic by partnering among one another to deliver social goods.

- Currently, there is no standard manner for comparing CSR practices between the construction sector and the manufacturing, mining and banking sectors. Henceforth, the sector characteristics and organisational structure attributes can be used to benchmark and compare CSR practices in the construction and the other sectors

- The sector characteristics and organisational structure attributes are contexts where CSR is implemented. In addition, these attributes aid successful (or otherwise) CSR implementation. Therefore, the context should be strongly considered in the implementation of CSR. In the construction sector, the context is the diverse professions and processes. To successfully implement CSR in this sector, it is either to build a unified operators to remove the elements of diversity, or to exploit the individual strength of the different operators for successful implementation of CSR.

- This study relied on the researchers' viewpoints to reveal the state of CSR in the construction sector. Therefore, only previous studies published in academic journals were used as source of information. To empirically confirm the findings in this study, the practitioner viewpoint of the state of CSR in the construction sector should be investigated. Insights for such investigation can be drawn from this study. Firstly, the state of CSR should be investigated across a wide range of construction organisations and projects. Secondly, cross-sectoral study of the state of CSR between the construction and other sectors should be investigated. Both the sector characteristics and organisational structure should be included as bases for comparison.

Globally, one crucial goal in the construction sector is to eliminate the negative impact of design and construction activities, and to increase social impact of construction through value-addition to clients, 
strong community relations, physical development and job creation in the rural areas. CSR can be deployed as a strategy to achieve this goal. For instance, National regulations can be put in place to compel construction companies to provide low-scale social amenities in the host communities of their projects. In addition, an evidence of past CSR practice can be included as basis for construction companies to tender for new contracts. This study has revealed unique insights, particularly regarding the implementation of CSR in the construction sector in terms of sector characteristics and organisational structure. Therefore, it is a sector guide and an organisational template for implementing CSR. This is one step closer to closer to the goal of a socially impacting construction sector.

\section{REFERENCES}

Abuya, W. O. (2016). Mining conflicts and Corporate Social Responsibility: Titanium mining in Kwale, Kenya. The Extractive Industries and Society, 3(2), 485-493.

Adogbo, K., Ibrahim, A., \& Ibrahim, Y. (2015). Development of a framework for attracting and retaining women in construction practice. Journal of Construction in Developing Countries, 20(1), 99.

Ali, E., \& Rahman, S. M. (2015). Corporate Social Responsibility Disclosure: A Comparative Study Between Islamic Banks and Conventional Banks in Bangladesh. International Business and Management, 10(1), 9-17.

Andrews, N. (2016). Challenges of corporate social responsibility (CSR) in domestic settings: An exploration of mining regulation vis-à-vis CSR in Ghana. Resources Policy, 47, 9-17.

Ayuso, S., Roca, M., Arevalo, J. A., \& Aravind, D. (2016). What determines principle-based standards implementation? Reporting on global compact adoption in Spanish firms. Journal of business ethics, 133(3), 553-565.

Barnes, L. R., \& Croker, N. (2013). The relevance of the ISO26000 social responsibility issues to the Hong Kong construction industry. Construction Economics and Building, 13(3), 37-50.

Barthorpe, S. (2010). Implementing corporate social responsibility in the UK construction industry. Property management, 28(1), 4-17.

Bevan, E. A., \& Yung, P. (2015). Implementation of corporate social responsibility in Australian construction SMEs. Engineering, Construction and Architectural Management, 22(3), 295-311.

Bouvain, P., Baumann, C., \& Lundmark, E. (2013). Corporate social responsibility in financial services: A comparison of Chinese and East Asian banks vis-à-vis American banks. International Journal of Bank Marketing, 31(6), 420-439.

Bowen, P., Allen, Y., Edwards, P., Cattell, K., \& Simbayi, L. (2014). Guidelines for effective workplace HIV/AIDS intervention management by construction firms. Construction Management and Economics, 32(4), 362-381.

Boyle, T., \& McGuirk, P. (2012). The Decentred Firm and the Adoption of Sustainable Office Space in Sydney, Australia. Australian Geographer, 43(4), 393-410.

Bravo, R., Buil, I., de Chernatony, L., \& Martínez, E. (2017). Brand Identity Management and Corporate Social Responsibility: an analysis from employees' perspective in the banking sector. Journal of Business Economics and Management, 18(2), 241-257.

Cadbury, A. (2006). Corporate social responsibility. Twenty-First Century Society, 1(1), 5-21.

Cambra-Fierro, J., Wilson, A., Polo-Redondo, Y., Fuster-Mur, A., \& Lopez-Perez, M. E. (2013). When do firms implement corporate social responsibility? A study of the Spanish construction and real-estate sector. Journal of Management \& Organization, 19(02), 150-166.

Castelo Branco, M., \& Lima Rodrigues, L. (2006). Communication of corporate social responsibility by Portuguese banks: A legitimacy theory perspective. Corporate Communications: An International Journal, 11(3), 232-248. 
Close, R., \& Loosemore, M. (2014). Breaking down the site hoardings: attitudes and approaches to community consultation during construction. Construction Management and Economics, 32(7-8), 816-828.

Dimmler, L. (2017). Linking social determinants of health to corporate social responsibility: Extant criteria for the mining industry. The Extractive Industries and Society.

Ekung, S., Ujene, A., \& Ebong, U. (2014). Drivers of corporate social responsibility within construction organization in Nigeria. International Letters of Social and Humanistic Sciences (ILSHS), 21, 14-

Forcadell, F. J., \& Aracil, E. (2017). European Banks' Reputation for Corporate Social Responsibility. Corporate Social Responsibility and Environmental Management, 24(1), 1-14.

Gingerich, E. (2010). Engaging Multidisciplinary University Students in" Triple Bottom Line" Reporting: Using Global Reporting Initiative Metrics Inside the Classroom. International Journal of Interdisciplinary Social Sciences, 5(7).

Glass, J., \& Dainty, A. (2011). The sustainable construction business: A missing ingredient in creating a sustainable built environment? International Journal of Construction Management, 11(2), 1-18.

Glass, J. (2011). Briefing: Responsible sourcing of construction products. In Proceedings of the Institution of Civil Engineers-Engineering Sustainability (Vol. 164, No. 3, pp. 167-170). Thomas Telford Ltd.

Gliedt, T., \& Hoicka, C. E. (2015). Energy upgrades as financial or strategic investment? Energy Star property owners and managers improving building energy performance. Applied Energy, 147, 430443.

Griffith, A. (2011). Fulfilling contractors' corporate social responsibilities using standards-based management systems. International Journal of Construction Management, 11(2), 37-47.

Graafland, J., \& Mazereeuw-Van der Duijn Schouten, C. (2012). Motives for corporate social responsibility. De Economist, 160(4), 377-396.

Grosser, K. (2009). Corporate social responsibility and gender equality: women as stakeholders and the European Union sustainability strategy. Business Ethics: A European Review, 18(3), 290-307.

Guo, W.-F., Zhou, J., Yu, C.-L., Tsai, S.-B., Xue, Y.-Z., Chen, Q., ....... Wu, C.-H. (2015). Evaluating the green corporate social responsibility of manufacturing corporations from a green industry law perspective. International Journal of Production Research, 53(2), 665-674.

Guo, W. (2012). A preliminary exploration on transformative social work model in China: a case study on social work with migrant construction workers. China Journal of Social Work, 5(1), 51-66.

Haigh, R., \& Sutton, R. (2012). Strategies for the effective engagement of multi-national construction enterprises in post-disaster building and infrastructure projects. International Journal of Disaster Resilience in the Built Environment, 3(3), 270-282.

Hamidu, A., Haron, M., \& Amran, A. (2015). Corporate Social Responsibility: A Review on definitions, core characteristics and theoretical perspectives. Mediterranean Journal of Social Sciences, 6(4), 83-95.

Handayani, R., Wahyudi, S., \& Suharnomo, S. (2017). The effects of corporate social responsibility on manufacturing industry performance: the mediating role of social collaboration and green innovation. Business: Theory and Practice, 18, 152.

Health and Safety Executive. (2017). Fatal injuries arising from accidents at work in Great Britain. Retrieved 30 November 2017from Health and Safety Executive, http://www.hse.gov.uk/statistics/fatals.htm

$\mathrm{Hu}$, V. i., \& Scholtens, B. (2014). Corporate social responsibility policies of commercial banks in developing countries. Sustainable Development, 22(4), 276-288.

Huang, C.-F., \& Lien, H.-C. (2012). An empirical analysis of the influences of corporate social responsibility on organizational performance of Taiwan's construction industry: using corporate image as a mediator. Construction Management and Economics, 30(4), 263-275.

Jenkins, H. (2004). Corporate social responsibility and the mining industry: conflicts and constructs. Corporate Social Responsibility and Environmental Management, 11(1), 23-34. 
Jiang, W., \& Wong, J. K. (2016). Key activity areas of corporate social responsibility (CSR) in the construction industry: a study of China. Journal of Cleaner Production, 113, 850-860.

Jimoh, R. A., Oyewobi, L. O., Adamu, A. N., \& Bajere, P. A. (2016). Women professionals' participation in the nigerian construction industry: finding voice for the voiceless. Organization, Technology and Management in Construction: an International Journal, 8(1), 1429-1436.

Kraft, K. L., \& Hage, J. (1990). Strategy, social responsibility and implementation. Journal of Business Ethics, 9(1), 11-19.

Lassch, O., \& Yang, J. (2011). Rebuilding dynamics between corporate social responsibility and international development on the search for shared value. KSCE Journal of Civil Engineering, 15(2), 231-238.

Lentner, C., Szegedi, K., \& Tatay, T. (2015). Corporate social responsibility in the banking sector. Pénzügyi Szemle/Public Finance Quarterly, 60(1), 95-103.

Li, D., Xin, L., Chen, X., \& Ren, S. (2017). Corporate social responsibility, media attention and firm value: empirical research on Chinese manufacturing firms. Quality \& Quantity, 1-15.

Liao, P.-C., Xue, J., Liu, B., \& Fang, D. (2015). Selection of the approach for producing a weighting scheme for the CSR evaluation framework. KSCE Journal of Civil Engineering, 19(6), 1549-1559.

Lichtenstein, S., Badu, E., Owusu-Manu, D.-G., John Edwards, D., \& D. Holt, G. (2013). Corporate social responsibility architecture and project alignments: A study of the Ghanaian construction industry. Journal of Engineering, Design and Technology, 11(3), 334-353.

Lin, X., Ho, C. M., \& Shen, G. Q. (2018). Research on corporate social responsibility in the construction context: a critical review and future directions. International Journal of Construction Management, 18(5), 394-404.

Liu, A. M., Fellows, R., \& Tuuli, M. M. (2011). The role of corporate citizenship values in promoting corporate social performance: towards a conceptual model and a research agenda. Construction Management and Economics, 29(2), 173-183.

Liyanage, C., Ulutaş Duman, D., Giritli, H., \& McDermott, P. (2016). Corporate social responsibility in construction industry: a comparative study between UK and Turkey. Built Environment Project and Asset Management, 6(2), 218-231.

Lu, W., Ye, M., Flanagan, R., \& Ye, K. (2015). Corporate social responsibility disclosures in international construction business: trends and prospects. Journal of Construction Engineering and Management, 142(1), 04015053.

Lund-Thomsen, P., \& Nadvi, K. (2010). Clusters, chains and compliance: corporate social responsibility and governance in football manufacturing in South Asia. Journal of Business Ethics, 93, 201-222.

Mariri, T., \& Chipunza, C. (2011). Corporate governance, corporate social responsibility and sustainability: Comparing corporate priorities within the South African mining industry. Journal of human ecology, 35(2), 95-111.

Mayr, S. (2015). Corporate Social Responsibility in SMEs: The Case of an Austrian Construction Company.

Mensah, H. K., Agyapong, A., \& Nuertey, D. (2017). The effect of corporate social responsibility on organizational commitment of employees of rural and community banks in Ghana. Cogent Business \& Management, 4(1), 1280895.

Mok, K. Y., Shen, G. Q., \& Yang, J. (2015). Stakeholder management studies in mega construction projects: A review and future directions. International Journal of Project Management, 33(2), 446-457.

Moomaw, W. R. (1996). Industrial emissions of greenhouse gases. Energy Policy, 24(10-11), 951-968.

Morioka, S. N., \& de Carvalho, M. M. (2016). A systematic literature review towards a conceptual framework for integrating sustainability performance into business. Journal of Cleaner Production.

Morton, P., Goodwin, A., Kellond, A., Close, K., \& Collins, J. (2011). Investing in the future construction workforce: CSR and work experience placements. International Journal of Construction Management, 11(2), 49-58.

Murray, M., \& Dainty, A. (2013). Corporate social responsibility in the construction industry: Routledge. 
Nodoushani, O. (2013). Child Labor and Corporate Social Responsibility: A Global Perspective. In Competition Forum (Vol. 11, pp. 148): American Society for Competitiveness.

Okoli, C., \& Schabram, K. (2010). A guide to conducting a systematic literature review of information systems research.

Olanipekun, A. O., Chan, A. P., Xia, B. P., \& Ameyaw, E. E. (2017). Indicators of owner commitment for successful delivery of green building projects. Ecological Indicators, 72(2017), 268-277.

Othman, A., \& Abdellatif, M. (2011). Partnership for integrating the corporate social responsibility of project stakeholders towards affordable housing development: A South African perspective. Journal of Engineering, Design and Technology, 9(3), 273-295.

Othman, A., \& Mia, B. (2008). Corporate social responsibility for solving the housing problem for the poor in South Africa. Journal of Engineering, Design and Technology, 6(3), 237-257.

Ozorhon, B. (2013). Response of construction clients to low-carbon building regulations. Journal of Construction Engineering and Management, 139(12), A5013001.

Panayiotou, N. A., Aravosis, K. G., \& Saridakis, K. (2009). An Exploratory Study of the Corporate Social Responsibility Practices in the Greek Manufacturing Sector. In Professionals' Perspectives of Corporate Social Responsibility (pp. 191-208): Springer.

Patnaik, S., Temouri, Y., Tuffour, J., Tarba, S., \& Singh, S. K. (2017). Corporate social responsibility and multinational enterprise identity: insights from a mining company's attempt to localise in Ghana. Social Identities, 1-20.

Petrovic-Lazarevic, S. (2010). Good corporate citizenship in the Australian construction industry. Corporate Governance: The international journal of business in society, 10(2), 115-128.

Petrovic-Lazarevic, S. (2008). The development of corporate social responsibility in the Australian construction industry. Construction management and Economics, 26(2), 93-101.

Pillania, R., Wuttke, M., \& Vilks, A. (2014). Poverty alleviation through CSR in the Indian construction industry. Journal of Management Development, 33(2), 119-130.

Piper, A. R. J. (2013). How to write a systematic literature review: a guide for medical students. National AMR, Fostering Medical Research, 1-8.

Pivo, G., \& Group, U. E. P. F. I. P. W. (2008). Responsible property investing: what the leaders are doing. Journal of Property Investment \& Finance, 26(6), 562.

Rapson, D., Shiers, D., Roberts, C., \& Keeping, M. (2007). Socially responsible property investment (SRPI) An analysis of the relationship between equities SRI and UK property investment activities. Journal of Property Investment \& Finance, 25(4), 342-358.

Roberts, C., Jones, P., Hillier, D., Comfort, D., \& Clarke-Hill, C. (2009). Commercial property investment companies and corporate social responsibility. Journal of Property Investment \& Finance, 27(5), 522-533.

Roberts, C., \& Kimmet, P. (2009). Comparing "socially responsible" and "sustainable" commercial property investment. Journal of Property Investment \& Finance, 27(5), 470-480.

Roberts, C., \& Kriese, U. (2009). Business and marketing strategies in responsible property investment. Journal of Property Investment \& Finance, 27(5), 447-469.

Russo, A., \& Perrini, F. (2010). Investigating stakeholder theory and social capital: CSR in large firms and SMEs. Journal of Business ethics, 91(2), 207-221.

Sallyanne Decker, O. (2004). Corporate social responsibility and structural change in financial services. Managerial Auditing Journal, 19(6), 712-728.

Sardinha, I. D., Reijnders, L., \& Antunes, P. (2011). Using corporate social responsibility benchmarking framework to identify and assess corporate social responsibility trends of real estate companies owning and developing shopping centres. Journal of Cleaner Production, 19(13), 1486-1493.

Sartor, M., Orzes, G., Di Mauro, C., Ebrahimpour, M., \& Nassimbeni, G. (2016). The SA8000 social certification standard: Literature review and theory-based research agenda. International Journal of Production Economics, 175, 164-181. 
Selmier, W. T. (2017). Mining history, poems and songs: Extensible lessons about extractable corporate social responsibility (CSR). The Extractive Industries and Society.

Sen, S. (2011). Corporate social responsibility in small and medium enterprises: application of stakeholder theory and social capital theory.

Sen, S., \& Cowley, J. (2013). The relevance of stakeholder theory and social capital theory in the context of CSR in SMEs: An Australian perspective. Journal of Business Ethics, 118(2), 413-427.

Shen, C.-H., Wu, M.-W., Chen, T.-H., \& Fang, H. (2016). To engage or not to engage in corporate social responsibility: Empirical evidence from global banking sector. Economic Modelling, 55, 207-225.

Shen, L.-y., Tam, V. W., Tam, L., \& Ji, Y.-b. (2010). Project feasibility study: the key to successful implementation of sustainable and socially responsible construction management practice. Journal of Cleaner Production, 18(3), 254-259.

Tan-Mullins, M., \& Mohan, G. (2013). The potential of corporate environmental responsibility of Chinese state-owned enterprises in Africa. Environment, Development and Sustainability, 15(2), 265-284.

Tang-Lee, D. (2016). Corporate social responsibility (CSR) and public engagement for a Chinese statebacked mining project in Myanmar-Challenges and prospects. Resources Policy, 47, 28-37.

ten Ham-Baloyi, W., \& Jordan, P. (2016). Systematic review as a research method in postgraduate nursing education. health sa gesondheid, 21(1), 120-128.

Tsai, W.-H., Yang, C.-H., Chang, J.-C., \& Lee, H.-L. (2014). An Activity-Based Costing decision model for life cycle assessment in green building projects. European Journal of Operational Research, 238(2), 607-619.

Uddin, M. B., Tarique, K. M., \& Hassan, M. (2008). Three dimensional aspects of corporate social responsibility.

Upstill-Goddard, J., Glass, J., Dainty, A., \& Nicholson, I. (2016). Implementing sustainability in small and medium-sized construction firms: the role of absorptive capacity. Engineering, Construction and Architectural Management, 23(4), 407-427.

Valentine, S., \& Godkin, L. (2017). Banking Employees' Perceptions of Corporate Social Responsibility, Value-Fit Commitment, and Turnover Intentions: Ethics as Social Glue and Attachment. Employee Responsibilities and Rights Journal, 29(2), 51-71.

Vigneau, L., Humphreys, M., \& Moon, J. (2015). How do firms comply with international sustainability standards? Processes and consequences of adopting the global reporting initiative. Journal of Business Ethics, 131(2), 469-486.

Wan-Jan, W. S. (2006). Defining corporate social responsibility. Journal of Public Affairs: An International Journal, 6(3-4), 176-184.

Wang, L., Toppinen, A., \& Juslin, H. (2014). Use of wood in green building: a study of expert perspectives from the UK. Journal of cleaner production, 65, 350-361.

Williams, A. (2003). Linking the environmental and social dimensions of corporate social responsibility. Centre for Business Relationships, Accountability, Sustainability \& Society, Cardiff University.

Wilson, L., Zuo, J., Zillante, G., Pullen, S., Burger, A., \& Chiveralls, K. (2011). Corporate social responsibility in the Australian construction industry.

Wirth, H., Kulczycka, J., Hausner, J., \& Koński, M. (2016). Corporate Social Responsibility: Communication about social and environmental disclosure by large and small copper mining companies. Resources Policy, 49, 53-60.

Wu, C.-L., Fang, D.-P., Liao, P.-C., Xue, J.-W., Li, Y., \& Wang, T. (2015). Perception of corporate social responsibility: the case of Chinese international contractors. Journal of Cleaner Production, 107, 185-194.

Wu, M.-W., Shen, C.-H., \& Chen, T.-H. (2017). Application of multi-level matching between financial performance and corporate social responsibility in the banking industry. Review of Quantitative Finance and Accounting, 49(1), 29-63.

Xia, B., Olanipekun, A., Chen, Q., Xie, L., \& Liu, Y. (2018). Conceptualising the state of the art of corporate social responsibility (CSR) in the construction industry and its nexus to sustainable development. Journal of Cleaner Production. 
Xiong, B., Lu, W., Skitmore, M., Chau, K., \& Ye, M. (2016). Virtuous nexus between corporate social performance and financial performance: a study of construction enterprises in China. Journal of Cleaner Production, 129, 223-233.

Xiong, B., Skitmore, M., \& Xia, B. (2015). A critical review of structural equation modeling applications in construction research. Automation in Construction, 49(2015), 59-70.

Yam Lee Hong, S., Ismail, M., \& Soo Yin, T. (2008). Corporate social responsibility in Malaysia housing development-the developer's perspective. Pacific Rim Property Research Journal, 14(2), 177-198.

Yam, S. (2013). The practice of corporate social responsibility by Malaysian developers. Property Management, 31(1), 76-91.

Zhang, J., Li, H., Olanipekun, A. O., \& Bai, L. (2019). A successful delivery process of green buildings: The project owners' view, motivation and commitment. Renewable Energy.

Zhao, Z.-Y., Zhao, X.-J., Davidson, K., \& Zuo, J. (2012). A corporate social responsibility indicator system for construction enterprises. Journal of cleaner production, 29, 277-289.

Zhao, Z.-Y., Zhao, Z.-Y., Zhao, X.-J., Zhao, X.-J., Zuo, J., Zuo, J., . . Zillante, G. (2016). Corporate social responsibility for construction contractors: a China study. Journal of Engineering, Design and Technology, 14(3), 614-640.

Zhu, Q., Zhao, T., \& Sarkis, J. (2011). An exploratory study of corporate social and environmental responsibility practices among apartment developers in China. College Publishing, 6(3), 181-196.

Zou, P., \& Couani, P. (2012). Managing risks in green building supply chain. Architectural Engineering and Design Management, 8(2), 143-158. 